\title{
Fasting, justification, and self-righteousness in Luke 18:9-14: A social-scientific interpretation as response to Friedrichson
}

\begin{abstract}
Authors:
Steven H. Mathews

Ernest van Eck ${ }^{1}$

\section{Affiliations:}

${ }^{1}$ Department of New

Testament Studies,

University of Pretoria,

South Africa

\section{Note:}

This article is based on the PhD thesis, 'A socialscientific interpretation of fasting in the New Testament as a critical analysis of fasting in contemporary evangelicalism', submitted in 2013 in the Department of Biblical and Religious Studies, Faculty of Humanities, University of Pretoria, with Prof. Dr Ernest van Eck as supervisor
\end{abstract}

\section{Correspondence to:} Ernest van Eck

Email:

ernest.vaneck@up.ac.za

Postal address:

Private Bag X20, Hatfield

0028, South Africa

\section{Dates:}

Received: 14 Mar 2013

Accepted: 21 July 2013

Published: 12 Sept. 2013

How to cite this article: Mathews, S.H. \& Van Eck, E., 2013, 'Fasting, justification, and self-righteousness in Luke 18:9-14: A socialscientific interpretation as response to Friedrichson', HTS Teologiese Studies/ Theological Studies 69(1), Art. \#1957, 9 pages. http://dx.doi.org/10.4102/ hts.v69i1.1957

Read online:

Scan this QR
code with your
smart phone or
mobile device
to read online.

This article provides a social-scientific interpretation of the role of fasting in Jesus' parable of the Pharisee and the tax collector in Luke 18:9-14. Specifically, the article considers such social realia as honour and shame, collectivism, and purity in the interpretation of the text. The textual and social contexts of the text are considered. It is contended that in the parable Jesus presents a caricature of both the Pharisee and the tax collector to make a larger point, in which fasting is not a major consideration. The article also evaluates Friedrichson's interpretation of this text, which depicts the Pharisee as fasting vicariously, resulting in the justification of the tax collector. Finally, the significance of this text in a holistic theology of fasting in the New Testament is considered.

\section{Introduction}

\section{Fasting in the New Testament from a social-scientific perspective}

The research goal of this article is to interpret Luke 18:9-14 in its theological, social, and cultural contexts, and to build from this interpretation a response to Friedrichson's interpretation that the Pharisee's fasting in the text is vicarious, performed on behalf of the publican as well as all of Israel. This article will contend that Friedrichson's interpretation does not take into account the intended rhetorical effect of the text, whereas a social-scientific reading of the text yields an interpretation that strikes closer to the meaning of the parable as transmitted to the original audience.

To that end, it will be useful to begin with a treatment of the social and cultural meaning of fasting in the 1st-century Mediterranean world. Broad cultural and social themes of fasting in the 1stcentury Mediterranean world will be sketched here, and some implications of the present text for a New Testament theology of fasting will be discussed.

Social-scientific criticism is an attempt to place the text of the New Testament into the social and cultural context of the 1st-century Mediterranean world. Elliott defines social-scientific criticism as a component of historical criticism (Elliott 1993:7), and identifies three critical relationships between the text and its cultural environment which must be taken into account in biblical exegesis, in addition to the form and content of texts:

1. The 'conditioning factors and intended consequences of the communication process' (Elliott 1993:7), that is, the paralanguage behind the text, the cultural and social implications of the words of the text in their original environment.

2. The 'correlation of the text's linguistic, literary, theological (ideological), and social dimensions' (Elliott 1993:7). Texts within their cultural environment are not viewed as one-dimensional; rather, the social-scientific critic attempts to take into account the interplay of factors (social, literary, theological, etc.) which together comprise the text in its social, canonical, and theological context.

3. The 'manner in which this textual communication was both a reflection of and response to a specific social and cultural context; that is, how it was designed to serve as an effective vehicle of social interaction and an instrument of social as well as literary and theological consequence' (Elliott 1993:7). Social-scientific critics attempt to interpret the text from a position of sympathy, to the extent that such sympathy is possible, with the 1st-century Mediterranean worldview, and to interpret the text as an occupant of that world might interpret it.

The task of social-scientific criticism is to 'provide a Western reader with basic Mediterranean cultural concepts with which to create appropriate scenarios for imagining what one is reading' (Pilch 2002:3-4). The challenges which befall such an interpreter are immediately obvious. The three barriers of time, space, and language present themselves at once. Two thousand years of 
history have erased many cultural and social conventions of the New Testament world, and the study of the Greek language does not convey all the cultural nuances present in the original context. The goal of social-scientific criticism, therefore, is forensic, namely, to reconstruct a social and cultural model(s) of the New Testament world, from which the reader may create hermeneutical scenarios for interpreting the text in its context. As Pilch (2002) notes, the New Testament world is a high-context society - much of the meaning in the textual communication was contained in its social and cultural context:

Reading and interpreting the Bible requires that the reader imagine scenarios for the books and passages being read. But the Bible is a high-context document. This means that the authors of the Bible safely assumed that they did not have to present their audiences or readers with all the details of the stories and events they were reporting. (p. 2)

Several social institutions are relevant to the parable under consideration. Below are discussed the concepts of honour and shame, dyadism, and limited good.

The primary social institution of the early Mediterranean world is honour. Honour is a social currency which can be gained or lost in one's relationship with others. Honour is the community's recognition of one's place within the larger community. Malina defines honour as 'a register of social rating which entitles a person to interact in specific ways with equals, superiors, and subordinates, according to the prescribed cultural cues of the society' (Neyrey 1991:26).

In the 1st-century Mediterranean world individuals were described by their relationship to the community at large. They would be identified by their location (Saul of Tarsus), by their nationality ('Cretans are always liars, evil beasts, lazy gluttons'; Tt 1:12), by their clan (Paul is a Benjamite, Mary is of the house of David), by family relationships (James and John are the sons of Zebedee), or by one's school of thought (Paul is a student of Gamaliel; Apollos received only the baptism of John). Such a view of the individual in society is known as dyadism. Pilch and Malina (1998) summarise:

Individual people are not known or valued because of their uniqueness, but in terms of their dyad, that is, some other person or thing. Dyadism, therefore, is a means value by which one's honor can be continually checked, affirmed, or challenged ... Personal identity and knowledge of this sort belong in a cultural world that is highly ordered and carefully classified, so that there is a place for everyone and everyone in his place ... It follows that such people tend to think of themselves and others in stereotypes which tell of their role and status: as fishermen and carpenters, as scribes and lawyers, as governors and kings. (p. 54)

This view of one's culture and society, and one's place in it, is in stark contrast to the radical individualism of the contemporary West. Neyrey (1991:72) notes that the individualistic perspective of most Western readers would be quite foreign to inhabitants of the 1st-century Mediterranean world, and would create dysfunction within this society.

Dyadic persons find their sense of identity in the context of several dyads, or others, which determine who their equals are and the social norms by which they may be judged. Social harmony is derived from knowing one's place in the world, and remaining within it.

Malina and Rohrbaugh place fasting within the context of the honour-shame society ${ }^{1}$ which forms the backdrop for the New Testament, articulating that fasting may take two forms: ritualised and non-ritualised. Ritualised fasting may be referred to as 'formal' fasting, or fasting which fulfils ceremonial or liturgical purposes. Non-ritualised fasting may be described in terms such as 'visceral', 'spontaneous', and 'emotional'. Malina and Rohrbaugh (2003) explain the social dynamics of non-ritualised fasting:

Fasting is a highly compressed piece of social behavior that can be either ritualized or nonritualized. It occurs in nonritualized form when persons are afflicted with overwhelming evil. The usual response to such evil is 'mourning': the inability to eat, sleep, worry about one's looks, worry about the state of one's clothing, etc. ... The proper social response to fasting and the mourning within which it is embedded is assistance on the part of the persons who are not mourning and need not fast. Nonritualized fasting, then, is social communication, intended to convey grief, suffering, and loss. It is an intentional display of shame in order to elicit the assistance of another, who may be a community member or God. Nonritualized fasting should then be seen as a radical act in an honor/shame society - intentionally losing honor and acquiring shame in the sight of others. This intentional acceptance of shame may obligate others to demonstrate honor through acts of mercy or largesse. (p. 360)

Where non-ritualised fasting may be directed at the community or at God, depending on its intent and context, ritual fasting is directed from the community to God. Ritualised fasting is an attempt (or begins as an attempt, which may over time become a mere formal exercise) to elicit the assistance of God in alleviating the suffering, or restoring the honour, of Israel.

In the New Testament, one finds both ritualised and nonritualised fasting. Indeed, in some texts (e.g. Lk 18:9-14) the distinction between the two may not be immediately clear.

Several hermeneutical possibilities emerge regarding the practice of fasting in the New Testament world, which are relevant to a social-scientific interpretation of fasting texts:

- Fasting can be an intentional dishonouring of oneself (and by extension, one's dyad, or larger group from which one derives one's sense of identity, and within which one's role is defined) in a society which prizes honour above all else.

- Fasting may place a moral obligation on the observer of the fasting - when one dishonours oneself by fasting, others are bound by honour to render assistance, particularly to members of their own family or dyad.

- Fasting may, alternatively, be used to acquire honour through demonstrating great devotion to God and to Israel. One who places piety and dyad above his or her own honour may thereby gain honour in the estimation of the community.

1.For further details on the concepts of honour and shame in 1st-century Mediterranean world, see Neyrey (1991:26-35). 
- Fasting may be personal, or may be undertaken on behalf of a greater portion of the community, such as the family, the tribe, or the nation of Israel.

- Fasting may be a deep, visceral response to personal or national suffering, or it may be a ritualised action which is devoid of personal or emotional import on the part of the one fasting.

In addition:

- Fasting in the gospels and Acts is influenced by fasting in the Jewish tradition, including the Old Testament and various extra-biblical Jewish traditions.

- Fasting may be indicative of a spiritual condition which leads to, or provides evidence of, justification.

In an interpretation of fasting in Luke 18:9-14, each of these factors (and possibly others) must be considered.

\section{Fasting in Luke 18:9-14}

Luke 18:9-14 (New America Standard Bible) reads as follows:

And He also told this parable to some people who trusted in themselves that they were righteous, and viewed others with contempt: Two men went up into the temple to pray, one a Pharisee and the other a tax collector. The Pharisee stood and was praying this to himself: 'God, I thank You that I am not like other people: swindlers, unjust, adulterers, or even like this tax collector. I fast twice a week; I pay tithes of all that I get.' But the tax collector, standing some distance away, was even unwilling to lift up his eyes to heaven, but was beating his breast, saying, 'God, be merciful to me, the sinner!' I tell you, this man went to his house justified rather than the other; for everyone who exalts himself will be humbled, but he who humbles himself will be exalted.

This passage in Luke 18 portrays Jesus presenting a parable 'to some people who trusted in themselves that they were righteous, and viewed others with contempt' (Lk 18:9). The immediate context does not identify Jesus' audience further, but one may surmise from the content of the parable that perhaps Pharisees were the intended audience. In this parable, Jesus sets up two caricatures: a Pharisee and a tax collector. One is redeemed, and the other is not. This article will identify the role of fasting in this parable, and will attempt to identify the contribution of this parable to a broader theology of fasting in the New Testament. It is beyond the scope of this article to articulate such a holistic fasting theology based on the New Testament, though such an effort has been undertaken by the author (see Mathews 2013).

Fasting is not a prominent feature of this parable. It is mentioned only once, in Luke 18:12, in which the Pharisee dutifully reports that he fasts twice a week. The parable is not about fasting per se, but rather, as Luke explains, about the dangers of trusting in one's own righteousness to be justified. Jesus' emphasis in this text is not on fasting, but on the Pharisee's reliance on his fasting to produce merit. Fasting is presented, alongside tithing, as evidence of the Pharisee's moral and spiritual uprightness. Fasting, in this case, is presented as evidence of the man's spiritual condition, rather than as an action which produces a certain result or expects a specific response from God. The immediate question of relevance to this article is whether Jesus leads his audience to believe that fasting is an act of merit that leads to justification before God; to put it another way, if fasting is indicative of a spiritual condition which leads to justification. Thus, the question is whether fasting produces, or constitutes, merit. As Bergant and Karris (1989) write:

The debate over faith and works is already engaged here. Jesus himself draws the shocking conclusion from the parable: the observant Pharisee goes home unjustified, the sinful tax collector is justified. The reversal maxim concludes the story. (p. 968)

\section{Textual context}

A proper interpretation of this parable will place it into its Lukan context. As Doran (2007) explains, the context of this parable leads the reader to associate it with other events, parables, and discourses that emphasise the grace of God:

In these stories, the unexpected happens: It is the Samaritan, the foreigner, who returns to thank Jesus for his healing and who is given salvation; little children become models of behavior; it is not the wealthy magistrate but Jesus' poor followers who will enter the kingdom of heaven; the Son of Man has to be mocked and put to death before he can come in triumph. In these stories are hints of capriciousness: Why is one taken, another left (17:34-35)? Why are some chosen, others not (18:7)? Is there any ground for the choice? The Samaritan praises God, and his faith saves him $(17: 15-16,19)$; the chosen ones call out to God persistently for vindication (18:7); the disciples leave all (18:29-30). But those who seek to keep their lives for themselves will lose their lives (17:33). The criterion thus seems to be that one must not consider one's life to be self-contained, but must recognize that God disposes. The parable of the Pharisee and the tax collector fits nicely within this general theme: not reliance on self but dependence on God's graciousness. (p. 270)

Indeed, in its immediate context in Luke 18, it is found between the parable of the unjust judge (Lk 18:1-8) and the story of the rich young ruler (Lk 18:18-27), which emphasise God's gracious response to faith on the part of his people. Just as he has presented caricatures in the unjust judge and the pesky widow, he presents caricatures of the Pharisee and the tax collector in this parable. Rather than reading the characters in the parable as representative of actual individuals, it makes sense to read them as examples of hyperbole: Jesus is making a point, rather than simply providing an account of events at a prayer service. Just as he uses hyperbole in responding to the rich young ruler (Lk 18:25), he uses hyperbole here in his depiction of the Pharisee. Downing (1992:96) refers to Jesus' parable here as 'subversive', and argues that Jesus' original audience would have heard it as such.

\section{Characterisation in the parable}

For the purpose of this article, the character in the parable that merits attention is the Pharisee, for it is he who is depicted as regularly practising fasting, and as making assumptions about the significance of his fasting for his spirituality. It may be rightly questioned whether the tax collector is presented in this parable as a model of piety in his own right. However, as the purpose of this article is to determine the role of fasting in the parable, emphasis is placed on the fasting Pharisee, rather than the publican, who is not depicted as fasting. 
Doran (2007) summarises the role of Pharisees in Luke-Acts, and writes:

There is thus a tension in the characterization of the Pharisees in Luke's work: some are good, some bad. When Jesus therefore identifies one of the characters in the story as a Pharisee, he is not automatically a bad character. What makes him bad is his selfaggrandizement, and I surmise that many Pharisees would have agreed with this assessment. Not all Pharisees thought that they were the upright ones and everyone else was to be despised, as noted above. (p. 269)

Thus, the Pharisee in the parable is employed to represent a specific spiritual perspective. Just as not all priests and Levites would leave a wounded man to die on the side of the road, and not every Samaritan would take responsibility for the wounded man's care (Lk 10:30-37), not every Pharisee would have trusted in his own righteousness and viewed others with contempt. Such a view of the Pharisees is overly simplistic, and does not take into account the complexity of the Pharisees as a religious movement, or the intricacies of individual personality and spirituality. This Pharisee should be seen as a caricature invented to make a specific point, rather than an attempt to depict typical Pharisaism. Indeed, there is no monolithic, unified depiction of the Pharisees in Luke-Acts.

The Pharisees were concerned with obedience to the laws of Yahweh, as was Jesus, though the risk of forsaking the spirit of the law for mere adherence to the letter of it was always present. Holmgren (1994:258) explains that the Pharisee provides a type for the Lukan audience of a person who has co-opted confessional faith to exalt himself and marginalise others. The Lukan Jesus is not the first to condemn this kind of religious and social posturing.

To the modern Western reader the Pharisee's speech is the height of arrogance and ostentation: to stand publically in a church service and verbally attest to one's own righteousness in comparison with others present would be scorned. Such behaviour would most likely have been anathema (outside a certain context) in 1st-century Judaism as well - thus, the caricature Jesus is presenting. The inclusion of such behaviour in the parable is a cultural cue to Jesus' audience that a larger point is being made through the use of hyperbole. Linnemann (1966:58) also sees Jesus' depiction as a caricature of contemporary Pharisaism. Snodgrass (2008:469) notes that if this parable is seen as presenting a caricature, then the tax collector may be seen as a positive example, or 'both men may be viewed as unacceptable alternatives.'

There was a context in which such self-attestation would have been appropriate, however, as Holmgren (1994) explains:

It seems clear that both the Pharisees and Jesus were intent on preserving the integrity and health of the covenant community. Still, it also appears that the Pharisees were more traditional in their outlook than was Jesus. The truth they stressed was that of which Psalm 1 speaks: One must be careful in relating to those whose lifestyle opposes and harms the flow of life in the torah community lest the community's own healthfulness be placed in jeopardy. The Pharisees stood within a tradition that called upon Jews to give unambiguous testimony of their commitment to the torah-gift that God had given them. It is against this background that we can understand some basic concerns of the Pharisaic tradition. (p. 256)

Deuteronomy 26:1-15 contains formulaic expressions of obedience and faithfulness which the Jews were to recite before the priest when bringing an offering. The recital includes both expressions of the faithfulness of God (Dt 26:7-9) and of the obedience of the one reciting the prayer (Dt 26:10, 13-14). It ends with a prayer for God's blessing (Dt 26:15). As in the parable in Luke 18:9-14, the affirmation of one's obedience is connected to the act of tithing. Several differences exist between the liturgy in Deuteronomy 26 and that presented by the Pharisee in this parable. In Deuteronomy, only specific actions are named, that is, the one praying recites what he or she has done or has not done, whereas Jesus' Pharisee begins by asserting his own unique, meritorious character ('I am not like other people'), and cites his fasting and tithing as evidence of this character. The liturgy in Deuteronomy ends with a prayer for God's grace and justification; the Pharisee in the parable assumes himself to be justified. Jesus' audience may have recognised the Pharisee's oratory as a parody of the Deuteronomic liturgy, intended to further emphasise Jesus' point about trusting in one's own righteousness.

Holmgren (1994:259) notes that the Pharisee's speech may illustrate one of the primary problems of Pharisaism in Jesus' day: 'Laws are emphasized, the covenant relationship is forgotten, and legalism emerges to shape religious faith into a form that is alien to its beginnings.'

Doran (2007) expands on the Pharisee's prayer as parody:

In fact, when looked at closely, the prayer of the Pharisee in the parable can be seen as a parody of the Qumran and rabbinic prayers. Although the latter thank God for graciously placing them by moral luck in the covenant, the former stresses his own moral achievement - he is not a predator, a wrongdoer, and an adulterer. The same can be said for his claims that he tithes all that he acquires, and that he fasts twice a week. Some passages in the Mishnah recommend that one tithe even the foodstuffs that one buys (m. Maas. 2.1), and scholars have pointed to these passages. But tithing applies only to food and drink, not to everything one acquires, such as a house, clothes, and so on. The Pharisee's expression is over the top. As for fasting, it is recommended in times of personal or communal disaster. But the constant practice of fasting would be a way of forming identity. Just as eating together is a sign of community, so not eating is also a means of self-identification. Here the Pharisee is dissociating himself from the community. Is he choosing to identify himself as a leader of the community, for the Mishnah (m. Taan. 1.4) recommends that, in times of drought, important members of the community should fast three days? Is the Pharisee's perpetual fasting an attempt to exalt himself? In sum, the Pharisee's prayer is a caricature and might have brought a smile even to the faces of real Pharisee bystanders. They might themselves have encountered such priggish behavior. (p. 267)

The Pharisee in the parable has clearly made the leap from faith to works as the basis of justification, from grace to law- 
keeping as the means of gaining favour with God, and this is precisely the point Jesus is making in his parables: trusting in one's own merit does not lead to justification with God. It is not out of the norm for prayer and morality to be connected to one another.

However, for personal morality, as opposed to divine mercy, to be the basis of prayer, as depicted here, would be offensive to Jesus' Jewish audience; thus, the use of hyperbole to make Jesus' point about spiritual self-reliance. As Holmgren (1994) writes:

In Jesus' parable in Luke, the same contrast of extremes occurs, namely, the comparison between the very religious Pharisee and the very sinful tax collector. We are dealing here with hyperbole. Luke uses broad, exaggerated word-strokes to make the story unambiguously clear: Prideful performance of one's religious obligations, combined with contempt for others, is no way to be righteous before God. (p. 253)

Downing (1992) proposes that the key to the interpretation of this parable is that Jesus is presenting caricatures to make his point about justification:

My suggestion, then, is that we agree to take the parable as presenting us with twin caricatures. Both have an initial plausibility, sufficient for the allusions to register. But then the ambiguity of each dawns on us, for the prayer of the pious and respectable Pharisee is as self-absorbed as is the prayer of the despised toll-collector. The hearer is then left puzzling, left to decide for herself or himself how to respond. Both characters are sure that God's welcome is restricted and conditional, and both are sure God holds public offenders at arm's length. So both are wrong? Thus the intention of the narrative, shorn of its frame, must be to suggest that the second prayer is as much a parody in its own way as is the first. The ambiguity is deliberate. The hope is we may prefer Jesus' offer of God's quite unconditional welcome, and respond appropriately. (p. 98)

From a social-scientific critical perspective, several realia are relevant to Jesus' caricature here. First, one might consider the reversal motif: Jesus dishonours the Pharisee by depicting him as not justified, whilst ascribing honour to the tax collector. Jesus' audience may have expected that Jesus would ascribe honour to the Pharisee on the basis of his status as a Pharisee, and of the good works which he cites as evidence of his honour. In contrast, Jesus ascribes honour to the tax collector (justification) and dishonours the Pharisee.

Purity is also a key social reality against which this parable is juxtaposed. The Pharisees as a group were concerned with purity; that is, with the fulfilment of the law so as to be pure, living without sin. It is this obedience to the law upon which the Pharisee bases his assumption of purity: he fasts twice a week, prays, and tithes. In Jesus' parable, purity, in the form of justification, is ascribed to the publican, who has not demonstrated conformity to the purity standards of the community, such as obedience to the law or participation on ceremonial cleansing. Again, the reversal maxim is evident: the Pharisee is not declared clean on the basis of his religious actions, whereas the tax collector is declared clean on the basis of his repentance.

\section{Exclusivity}

Jesus' parable presents an exclusive picture of redemption: not everyone who expects to be justified is justified. Two men went to the temple to pray: a contrast is presented, not unlike the case of the two sons in Luke's parable in 15:11-32. As in this prior parable, the audience is surprised by the grace of God in justifying the sinner; that is, the one who might be assumed to be justified because of his conformity to social, cultural, and religious purity standards, is rejected (or is not honoured), and the other, who has not conformed to these standards, is accepted. Though a similar contrast is presented in the two parables, the parable of the prodigal son does not contain the exclusivity of the parable of the Pharisee and the tax collector. The father in the previous parable receives the prodigal son home, but does not reject the son who stayed home; indeed in Luke 15:31, the father affirms that the son has always been with him, and that he shares in all the father's possessions. However, Jesus clearly states that the tax collector went home justified, and that the Pharisee did not (Lk 18:14). In this respect, this parable is similar to the parable of Lazarus and the rich man in Luke 16:19-31, in which two men are compared. Both die; the rich man goes to Hades, whilst Lazarus, the beggar, goes to the bosom of Abraham (Lk 16:22-23). The paradigm of exclusivity is similar between this parable and the one under present consideration: one man is justified before God, and the other is rejected. This paradigm of exclusivity would have been familiar to Jesus' Jewish audience, being found as far back in the Old Testament as, for example, the accounts of Cain and Abel (Gn 4), Jacob and Esau (Gn 25), and Saul and David (1 Sm 13-18). Kodell notes that parallels are also to be found in the events immediately following this parable: the blessing of the children (Lk 18: 15-17) and the rich young ruler (Lk 18:18-25):

Again, the technique is that of exemplary pairs. The Pharisee and the tax collector of vv. 9-14 are paralleled with the rich ruler and the children of vv. 15-25. (Kodell 1987:423)

The children are presented as a model for entering the kingdom of God, whilst the rich young ruler went away sorrowful. Exclusivity, as applied to the interpretation of these parables, refers not to the nation of Israel as a whole, but to specific individuals: some people are excluded from acceptance, honour, or justification, whilst others are accepted, honoured, and justified.

Not all scholars favour this exclusive interpretation. Doran (2007), for example, writes that:

One has to decide whether the comparative form is to be read as exclusive or as properly comparative. As far as I can see, the only factor in the context that has led interpreters to choose an exclusive meaning is a disinclination to say that a Pharisee is

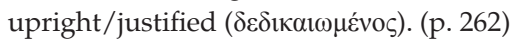

It seems that Jesus goes beyond a passive disinclination to acknowledge the justification of the Pharisee, however. He makes a clear contrast in Luke 18:14: 'this one ... rather than the other ...' Jesus is not, in this parable, comparing ways to be justified; he is warning those who trust in themselves 
and their religious acts of merit, rather than the grace of God (Lk 18:9, 14).

Doran favours a scaled, comparative interpretation, rather than an exclusive one. He rightly points out that both moral actions and an attitude of repentance are crucial in Judaism, and that this story presents an agonistic contrast between an 'over-emphasis on moral effort' for righteousness, and repentance for sins (Doran 2007:268).

Again, reading this parable, it does not appear that Jesus is teaching that repentance is more important than moral effort, but that self-righteous moral effort (i.e. trusting in one's own righteousness on the basis of one's moral or spiritual exertions) does not lead to justification. It is significant to note that there is no mention in this parable of moral effort combined with a repentant spirit, though this is certainly the most desirable spiritual condition, both for Jews and for Christians. To that extent, this parable teaches simply that moral effort devoid of repentance does not lead to justification; it goes no further.

This distinction between repentance, on the one hand, and moral effort devoid of repentance, on the other, would have been a familiar one to Jesus' audience. Blake (1972) notes:

In any case, these two religious men, about whom Jesus told his short story, came out of a tradition which took it for granted that when you pray it is not a substitute for right living but ought to be its inspiration, its blessing, and a help to some discrimination between right and wrong. (p. 133)

Though Doran sees this parable as comparative rather than exclusive, he correctly notes that the distinction between the two men gets to the point of Jesus' story; that 'the resolution is part and parcel of the story itself' (Doran 2007:263).

The contrast between the two men is evident in the language Luke uses to describe them. Kodell (1987) points out some key lexical features of this parable:

The word dikaioi (v. 9) prepares for dedikaiōmenos (v. 14), but in an ironic sense, because true righteousness cannot be accompanied by contempt for others. The word exouthenountas (v. 9) relates to the attitude of the disciples and the Samaritans (9:49, 54-55; 18:15). The word statheis (v. 11), found only in Luke-Acts, probably implies here a pompous attitude; hestōs (v. 13), referring to position rather than posture, implies receptive lowliness. (p. 424)

Though the interpretation of the parable seems straightforward, Jesus does offer an explanation in Luke 18:14. Downing (1992) notes that this explanation may be explained by the fact that the parable does not provide a satisfactory conclusion for Jesus' audience:

In 18:9-14 as it stands we have thus seventy-six words of narrative and a further forty-one of explanatory gloss. It must then be allowed that it would be very strange indeed for an author to compose and deploy a parabolic narrative that he or she saw as so inadequate on its own for its intended purpose as to need more than half as many extra words as were used for the narrative itself than to resolve its ambiguity and make it say what the narrator meant. It does look very much more as if
Luke received from the tradition a story of two people praying, where (irrespective of original intention) the second example met with his strong approval. Yet he was also sufficiently aware of contemporary discussions of prayer to realize that as it stood many might on reflection find both men equally obtuse. (p. 97)

Some parables seem to be more satisfying than others. The parable immediately preceding the one under consideration, for example, offers such satisfaction. A corrupt judge earns the scorn of Jesus' audience (he has dishonoured himself with corruption), whilst the widow is ascribed honour for her persistence despite her poverty (Lk 18:1-8). As such, this parable provides a clear-cut villain and a corresponding hero. The audience goes away satisfied that God's justice has been meted out in a way that conforms to their theological, cultural, and social norms. The present parable, however, offers little satisfaction because neither man is clearly a hero or a villain. Downing (1992:98-99) notes that many such 'unsatisfying' parables are to be found in Luke, including the parable of the unjust steward, the parable of the talents, and the parable of the vineyard owner. Some parables do not seem to make a clear, positive point, and are subversive in nature.

What, then, might this parable teach about Jesus' view of fasting in relation to justification? Perhaps simply that fasting as well as tithing are not necessarily indicators of a spiritual condition that is pleasing to God. The Pharisee fasts, yet he is rejected. This rejection is not based on his fasting, but on his confidence in his own righteousness on the basis of his moral endeavours, including fasting. Two important omissions in this parable must be taken into account when incorporating this text into a New Testament theology of fasting. Firstly, that Jesus neither praises nor condemns fasting here. He simply presents fasting, along with tithing, as examples of the behaviour of a caricature of self-righteousness. Secondly, Jesus does not discuss God's acceptance or rejection of a believer who both fasts and repents. He does not discuss what may be called 'righteous fasting' - fasting that is truly part of a pious, repentant life. This is the ideal of Christian fasting, but is not discussed in this parable. There are no positive examples of holy living in this parable, simply a portrait of a self-righteous, self-serving Pharisee and a (temporarily, perhaps superficially) repentant tax collector. Neither man is presented as a model of piety. In many ways, Jesus rejects such simplistic portrayals of religious life, as Downing (1992) notes:

If we choose to reject the words and actions of the second figure as well as those of the first, we find ourselves affirming the kind of approach to God that Jesus in the tradition elsewhere teaches. By the criterion of coherence it seems to have as good a claim as any other to be Jesus' own. (p. 99)

Schottroff (2006) notes the contrast and resulting exclusivity in this parable, and asserts that the contrast is read:

as a contrast between two mutually contradictory theological concepts: works righteousness versus sola gratia, the grace of God that cannot and need not be achieved through human works. These two theological concepts are implicitly or explicitly assigned to Christianity or Judaism/Pharisaism. (p. 10) 


\section{Vicarious fasting: Friedrichson's interpretation}

One other interpretation of fasting in this text merits consideration: that of Friedrichson, who sees the Pharisee's moral endeavours as justifying not himself, but others. Perhaps, according to Friedrichson, the Pharisee fasted vicariously, and the merit produced affected the tax collector. Friedrichson's theory deserves mention because he is one of the very few commentators who assign a primary role to the importance of fasting in this text. Perhaps Friedrichson has gone further than Luke in this regard. If fasting is indeed simply an example of exaggerated piety attributed to a caricature of self-righteousness, then it is not necessary to attempt to extrapolate further significance. Friedrichson, however, interprets the parable differently. His interpretation is explained below. Following this explanation, reasons for preferring the interpretation above will be given.

Friedrichson takes Jesus' depiction of the Pharisee's behaviour quite literally, rather than as a caricature. The Pharisee's fasting and tithing, for Friedrichson (2005), are not simply examples of moral and spiritual behaviour intended to verify the Pharisee's claims to be more righteous than others, but carry a significance of their own:

The Pharisee continues his thanksgiving by enumerating the

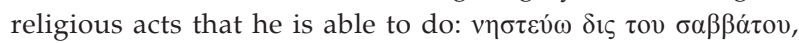

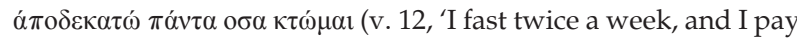
tithes on my whole income'). In both of these acts the Pharisee goes above and beyond what is required. With respect to the Torah, fasting was required only on the Day of Atonement (Lev 16:29-34; 23:27-32; Num 29:7-11). By the first century C.E., however, Purim and other national holidays included fasting. Moreover, fasting was seen as a virtuous, meritorious deed for the purposes of penance, mourning, remorse; it was also considered preparation for service, for communing with God, and even for the Messiah. (p. 110)

Fitzmyer (1985) points out that this text is distinctive in its reference to fasting twice a week:

This passage is the earliest attestation of the custom of the Jews fasting twice a week. Didi 8:1 instructs Christians that they are not to fast 'with the hypocrites' on the second and fifth days of the week, but on the fourth day and on the parasceve (= day of preparation for the Sabbath) ... Two days not contiguous with the Sabbath and themselves as far apart as possible, hence Monday and Thursday. (p. 187)

Friedrichson (2005) concludes that the Pharisee's bi-weekly fasting is not hyperbole on Jesus' part, but an indication of the Pharisee's concern for his community - that he fasted for others who could not, or would not, fast:

Thus, not only is this Pharisee conscientious about tithing (and fasting), but he also seems to have the weightier matters of the law (see, as noted above, Luke 11:42//Matt 23:23) in mind by his willingness to go above and beyond what is required for the sake of those who could not fulfill their duty. (p. 111)

Thus, for Friedrichson, the Pharisee's fasting was vicarious: it was done not for his benefit, but for others. What is the basis for such an interpretation? For Friedrichson, it is found in the temple liturgy. Under the law, justification required a sacrifice, and in this text, no sacrifice is mentioned. A man has gone home justified on the basis of his prayer alone, with no sacrifice offered. Friedrichson (2005) concludes that the fasting and tithing of the Pharisee is, in fact, the sacrifice which justified the tax collector:

With the observation that no explicit reference to sacrifice had been made by the storyteller, hearers may have continued to struggle to explain how it could be that the tax collector went down from the temple justified. Might a hearer suggest that the tax collector went down justified because he had benefited from the vicarious virtue of the Pharisee's fasting and tithing? What else does the storyteller offer his hearers? Unquestionably it is God who had effected the justifying, as the perfect passive participle $\delta \varepsilon \delta \iota \kappa \alpha \omega \mu \varepsilon ́ v o \varsigma$ indicates. (p. 117)

Friedrichson is not alone in his interpretation. Snodgrass (2008:467) states that the Pharisee 'probably viewed himself as fasting to make atonement for all of Israel.' Linnemann (1966:59) writes that the Pharisee 'variously makes atonement for the sins of his people, by fasting twice a week.'

Friedrichson's theory is an interesting one, and would have significant import for a New Testament theology of fasting, if indeed such an interpretation is justified. However, several reasons exist to temper Friedrichson's interpretation in light of the one articulated above. The first reason strikes at the centre of Friedrichson's theory that the temple liturgy required a sacrifice in order for justification to take place. Whilst there was indeed a sacrificial system in place, not every visit to the temple required a sacrifice. The most natural reading of the parable points to the Tamid, or afternoon prayer service, as Hamm indicates (Hamm 2003:223; see also Bailey 1983:145). If this is the case, the Friedrichson's argument is undermined, as sacrifices were not typically offered at such a service. Friedrichson (2005) writes:

Nevertheless, in the context of the temple, that divine action is normally connected with the sacrifice, so without explicit mention of the temple sacrifice, it does not seem unreasonable to propose that the original hearers would have searched for something with which to replace the sacrifice. Given that the storyteller does explicitly mention the Pharisee's righteousness, fasting, and tithing, all of which go above and beyond, perhaps some hearers may have connected these with God s justification of the tax collector. Although it is difficult to find contemporary texts to support this connection, that Exod 30:16 already connects the payment of the temple tax with atonement seems to allow the suggestion of a similar understanding of the tithing, which also supported the temple. Moreover, that the Pharisee tithes $\pi$ óvta

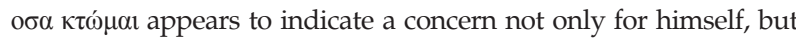
also for those who did not or could not pay their tithes. (p. 117)

A sacrifice would not have been required at a daily prayer service, but only on specific occasions. Friedrichson's theory is based on an assumption about the possible reaction of some members of the original audience of the parable:

So again, in the absence of the temple sacrifice and in the face of the Pharisee s tithing and fasting, some original hearers may have connected the latter with the tax collector having been made 'upright in the sight of God' by God. (Friedrichson 2005:117)

However, this assumption is not fully warranted, as a sacrifice would not have been required at a Tamid service. 
Additionally, three problems arise when basing one's interpretation on assumptions about the understanding of the original audience. The first is that often the assumptions amount to no more than wild guesses. Did Jesus' audience interpret his parable as teaching that the vicarious fasting and tithing of the Pharisee justified the tax collector? We do not know. Could another scholar produce another assumption? Certainly. Such assumptions often constitute eisegesis: reading into the text, rather than out of the text, a meaning which may not be present. Whilst all science, including hermeneutics, works with informed assumptions, basing an interpretation on an assumption as tenuous as this one - that the original audience would have assumed that a sacrifice was required at a Tamid service for worshipper to be justified - leaves plenty of room for error.

Second problem is that interpretations such as Friedrichson offers do not take into account the actual text. In this instance, Luke has provided a key to interpreting the parable at the very beginning: the parable was told to those who 'trusted in themselves that they were righteous, and viewed others with contempt' (Lk 18:9). The Pharisee's prayer indicates such contempt for others, such as the tax collector, who is singled out in the prayer (Lk 18:11). To assume that a man who holds others in such contempt is actually fasting and tithing vicariously and sacrificially on their behalf is quite a leap. All evidence in the text indicates that the Pharisee is depicted as confident in his own righteousness based on his actions, but no indication is given of his concern for the righteousness of others.

The third problem is that the meaning of the parable is decided by the narrator, not the audience. A social-scientific interpretation attempts to derive the intended rhetorical effect of the text from the original author to the original audience, in their shared social and cultural context. Thus the question is not so much 'what did the original audience assume the parable (or the written account of it in Luke) meant?' as 'what did Jesus or Luke intend to communicate to their audience?' Is it possible that some members of Jesus' audience interpreted this parable along the lines that Friedrichson portrays? Certainly it is possible that some members of any audience may give particular meaning to a discourse, but this understanding does not give a new, valid meaning to the discourse. Friedrichson's interpretation is not based on what Luke writes explicitly, but on what some audience members may have inferred. Such a hermeneutic is subjective at best. This may be illustrated in Friedrichson's (2005) own words:

If any of Jesus' hearers made such a connection it would be hard to overestimate the shock, dismay, and perhaps even anger of the original audience. How else would a pious Pharisee react upon hearing that his fasting and tithing might benefit even a tax collector? How else would other (peasant) hearers, who may have heard themselves reflected or at least implied in the sins listed by the Pharisee, react to this ending? These hearers may even have been hoping that the Pharisee's fasting and tithing might benefit them in their inability to do either. How are they to react upon hearing that the Pharisee's supererogation may benefit, of all people, their nemesis, a tax collector? That is, the one who benefits is precisely the one whose occupation contributes to their inability to pay their tithes (and, perhaps, the temple tax). But so it is with the kingdom of God, according to Jesus' parable. Expectations, even those connected with the temple, do not obligate the kingdom of God. (p. 118)

Where are the shock, dismay, and anger of Jesus' audience in the text? There is none. The gospels record many instances of conflict between Jesus and the Pharisees, yet this parable produces no such conflict. Immediately after the recitation of the parable, a minor conflict does indeed occur: Jesus' disciples rebuke parents who bring their children to Jesus to be blessed, and Jesus in turn rebukes his disciples and blesses the children (Lk 18:15-17). No conflict, shock, dismay, or anger on the part of Jesus' audience is depicted in the text in response to the parable; it is inferred by Friedrichson.

This very lack of conflict lends credence to the interpretation of this parable as hyperbole. Had the Pharisees in Jesus' audience viewed the parable as a challenge, social customs of the day would have demanded a response in the form of a riposte. If they heard the parable as a tongue-in-cheek caricature of ostentatious self-righteousness, they could easily agree with Jesus, exempt themselves personally from his caricature, and thus not feel constrained to offer a riposte, having not personally been shamed by his portrayal.

Friedrichson (2005) applies his interpretation to contemporary followers of Jesus as follows:

Who, then, can be secure in her or his religious observations? What if God refuses to be obliged by any group that makes exclusive claims on the way to salvation? What if all theologies - if the term can be applied - of indulgences, novenas, or First Friday observances are not games the kingdom cares to play? What if whatever benefits any of these practices by an observant person might effect washes over some unobservant one? What if any or all intercessory prayer uttered in worship services or in private help the intercessors' nemeses as much as or even more than those persons in the intercessors' hearts and minds? What if morality, however important, in the end is not the main concern of the kingdom? (p. 118)

Whilst reasons have been given to reject Friedrichson's interpretation of the parable, one can agree with him on this point: the purpose of Jesus' parable was indeed to indicate that acts of moral endeavour do not justify the moral actor apart from the grace and favour of God.

\section{Application to a New Testament theology of fasting}

Having interpreted the significance of fasting in this parable, attention is now turned to the significance of this text in formulating a New Testament theology of fasting. It is important to go no further in this respect than Luke does, so as to avoid Friedrichson's error of ascribing more significance to the act of fasting in this text than the original author. In this respect, one can say simply that this parable teaches that fasting, like tithing, does not, in and of itself, lead to righteousness or justification. Fasting, tithing, and 
prayer are all abused by the Pharisee in the parable for his own self-aggrandisement, and though fasting, tithing and prayer may all be genuine acts of piety and part of a holy life, the potential exists for these disciplines to be emptied of true religious significance by personal pride and self-reliance.

In addition to the Pharisee trusting in himself that he was righteous on the basis of his moral endeavours, he also viewed others with contempt. The potential exists for a follower of Jesus who practises disciplines such as fasting to look with contempt on others who do not practise these disciplines. Thus, this parable provides a negative example of fasting divorced from true piety. There are both vertical and horizontal dimensions in the text: the Pharisee has trusted in righteousness he did not possess (vertical), and has looked with contempt on his fellow man (horizontal).

\section{Conclusion}

In conclusion, this article introduced the social-scientific critical method as a viable approach to Jesus' parable in Luke 18:9-14, and proceeded to apply social-scientific criteria to the text, including textual and social aspects of the parable, to arrive at an interpretation of the text which emphasised the role of such social realia as honour, exclusivity, justification, and purity. Friedrichson's interpretation, which sees the Pharisee's fasting as done on behalf of others, and resulting in the justification of the tax collector, was reviewed, and it was demonstrated that a social-scientific interpretation of the text is not compatible with Friedrichson's conclusions. Finally, some aspects of the role of this text in formulating a viable New Testament theology of fasting were presented.

Perhaps the main thrust of this parable, as it relates to fasting, is a familiar one to theologians through the ages: the conflict between a works-based righteousness and a grace-based righteousness. The reformers placed an emphasis on grace for righteousness, with the rallying cry of sola gratia, rejecting their perception of the works-based righteousness of the Roman Catholic Church of their day. They believed that works-based righteousness and grace-based righteousness were mutually exclusive: one cannot be justified by grace and by works. Calvin (1972), commenting on this text, highlights the contrast between grace and works in the parable:

... just as the Pharisee's virtues were stinking and polluted with depraved confidence, so that his laudable goodness before men counted for nothing with God, so the publican obtained righteousness by no help of the merits of his works but only by his prayer for pardon ... the one foundation of our faith is that God accepts us, not because we deserve it, but because He does not impute our sins. (p. 130)

\section{Acknowledgements Competing interests}

The authors declare that they have no financial or personal relationship(s) which may have inappropriately influenced them in writing this article.

\section{Authors' contributions}

This article represents a reworked version of aspects from the PhD dissertation of S.H.M. (University of Pretoria, 2013), with E.v.E. (University of Pretoria) as supervisor.

\section{References}

Bailey, K.E., 1983, Poet and peasant and through peasant eyes: A literary-cultura approach to the parables in Luke, Eerdmans, Grand Rapids.

Bergant, D. \& Karris, R.J., 1989, The Collegeville Bible commentary, Liturgical Press, Collegeville.

Blake, E.C., 1972, 'Prayer and morality', Theology Today 29(2), 133-137. http://dx.doi. org/10.1177/004057367202900201

Calvin, J., 1972, Calvin's New Testament commentaries, vol. 2: Matthew, Mark, and Luke, transl. T.H.L. Parker, Eerdmans, Grand Rapids. PMid:4669758

Doran, R., 2007, 'The Pharisee and the tax collector: An agonistic story', Catholic Biblical Quarterly 69, 259-270.

Downing, F.G., 1992, 'The ambiguity of "the Pharisee and the toll-collector" (Luke 18:9-14) in the Greco-Roman world of late antiquity', Catholic Biblical Quarterly 54, 80-99.

Elliott, J.H., 1993, What is social-scientific criticism?, Fortress Press, Minneapolis.

Fitzmyer, J.A., 1985, The gospel according to Luke: X-XXIV, Doubleday, New York.

Friedrichson, T.A., 2005, 'The temple, a Pharisee, a tax collector, and the kingdom of God: Rereading a Jesus parable (Luke 18:10-14a)', Journal of Biblical Literature 124(1), 89-119. http://dx.doi.org/10.2307/30040992

Hamm, D., 2003, 'The Tamid service in Luke-acts: The cultic background behind Luke's theology of worship (Luke 1:5-25; 18:9-14; 24:50-53; Acts 3:1; 10:3, 30)', Catholic Biblical Quarterly 25, 215-231.

Holmgren, F.C., 1994, 'The Pharisee and the tax collector', Interpretation 48(3), 252-261. http://dx.doi.org/10.1177/002096439404800304

Kodell, J., 1987, 'Luke and the children: The beginning and end of the Great Interpolation', Catholic Biblical Quarterly 49, 415-430.

Linnemann, E., 1966, Parables of Jesus: Introduction and exposition, SPCK, London. PMid:5226201

Malina, B.J. \& Rohrbaugh, R.L., 2003, Social-science commentary on the synoptic gospels, Fortress, Minneapolis. PMCid:PMC275558

Mathews, S.H., 2013, 'A social-scientific interpretation of fasting in the New Testament as a critical analysis of fasting in contemporary evangelicalism', PhD thesis, Department of Biblical and Religious Studies, University of Pretoria.

Neyrey, J.H. (ed.), 1991, The social world of Luke-Acts, Hendrickson, Peabody.

Pilch, J.J. \& Malina, B., 1998, Handbook of biblical social values, Baker, Grand Rapids. PMCid:PMC1219424

Pilch, J.J., 2002, Cultural tools for interpreting the good news, Liturgical Press, Collegeville.

Schottroff, L., 2006, The parables of Jesus, Fortress Press, Minneapolis.

Snodgrass, K., 2008, Stories with intent: A comprehensive guide to the parables of Jesus, Eerdmans, Grand Rapids. 